\title{
INTEGRATED TECHNOLOGY IN TEACHING DEVELOPMENTAL MATH COURSES TO INCREASE STUDENT'S CRITICAL THINKING ABILITY
}

\author{
Qingxia Li \\ Department of Mathematics and Computer Science, \\ Fisk University, Nashville, Tennessee, USA \\ Xinyao Yang \\ Department of Mathematics, University of Missouri, Columbia, MO \\ Gloria Payne \\ Department of Natural Sciences, \\ Elizabeth City State University, Elizabeth City, NC
}

\begin{abstract}
This project examines the differences in student's Critical Thinking ability by comparing student's Pretest and Posttest through the WatsonGlaser Online Assessment. The targeted courses are the developmental mathematics courses at an open admission institution in the Midwest of United States. The methodology is to apply technology such as learning software and platforms in these courses. Data is collected and analyzed under both traditional condition without technology and experimental condition with technology. Results showed that students from classes with technology had a higher increase in the ability of Critical Thinking and mathematics knowledge. The model of integrating technology in teaching developmental mathematics courses should be adapted.
\end{abstract}

Keywords: Critical Thinking, SMART Technology, MOODLE, MyMathlab, Video Lecture

\section{Introduction}

John Dewey (Dewey, 1910) is one of many educational leaders who recognized that a curriculum aimed at building thinking skills would benefit the individual learner, the community, and the entire democracy. Critical thinking has many definitions. McPeck (McPeck, 1982) defined critical thinking as thinking with scepticism about a subject or field. Critical thinking can include certain aspects of problem solving and various skills. While 
Reichenbach (Reichenbach, 2000) denotes critical thinking as a process of interpreting, analyzing, evaluating, and synthesizing information to form a good understanding, judgement, or solution. Simply acquisition of skills are not enough to meet with the demands in the development of our society and it requires us to think critically and solve a variety of complicated problems. Dewey (Dewey, 1910) states that "if we teach today as we taught yesterday, we rob our children of tomorrow". Fortunately, a wide range of technological tools are available for integration into today's classrooms to better prepare our students for the challenges they will face in the future.

Students in STEM disciplines (Allen, 1981) often experience difficulties as a result of their inability to see that multiple interpretations of the same data can coexist. Understanding the different stages of thinking will help instructors in these fields to choose the most appropriate way of presenting the course content so that students can make the transition from one stage of thinking to the next smoothly. The instructors should distinguish between an idea and the name of that idea, between facts and conjectures, and be aware of student's thinking process. Aarons (Aarons, 1985) especially discussed why one should care about critical thinking, especially among American students, and how to increase or decrease student's critical thinking ability. Nelson (Nelson, 1982) introduces some key aspects of the pedagogy of critical thinking and their relationships through collaborative learning. In addition to explaining the basic concepts, it is important to point out the common errors and why the incorrect answers occur. He included inclass group exercises to accomplish this level of critical thinking.

However, technology (Brouwer, 1996) is widely used as a means of improving the quality of teaching and learning. Moll and Allenn (Moll \& Allen, 1982) uses video and discussion in class to enable students to derive concepts from the collected data, apply concepts in real life examples and practice scientific processes in a biology class at West Virginia University. They used a pretest/posttest to measure the difference in students' critical thinking skills pretest/posttest. The Reason! Project (Gebler, 2001) at the University of Melbourne has developed the Reason!Able software as part of a general method aimed at enhancing critical thinking skills. Rather than tinkering with existing methods, they are building afresh from solid foundations in cognitive science. They found a consensus around the unsurprising idea that cognitive skills, like other skills, improve with practice which should be motivated, guided, scaffolded, graduated and providing feedback. Students using Reason!Able appear to make dramatic gains.

Many strategies have been implemented at an open admission, historical black institution in the Midwest of United States in an effort to improve student learning experience. Faculty members spurred active engagements of students by providing them with an outline of notes. In 
addition, student group discussions were applied in the classrooms. This is a sub-project of the Elizabeth City State University-Minority Science and Engineering Improvement Program (ECSU-MSEIP), which addresses the growing shortage of qualified and competent STEM majors by strengthening course curricula through the infusion of critical thinking through technology (CTTT). The majority of students from this open admission and minority serving institution come from socially, economically, culturally and academically disadvantaged backgrounds, and qualify for the Pell Grant and other financial assistance. Minorities represent only a small fraction of the sparse population of qualified scientists in STEM disciplines. Thus, the STEM Programs in this institution provide a national advantage to potential STEM majors through easy accessibility and other similar factors.

In this paper, SMART Software and Pearson's Mymathlab were implemented in the developmental mathematics courses to increase student's critical thinking ability. The Watson-Glaser online assessment is used to analyze the data collected from these courses.

\section{Methodology}

The course-Basic Math and Algebra. This course is a remedial math course at a historically black institution in Midwest of the United States. This course provides an opportunity for the mathematically unprepared college students to get ready for their upper level math requirements in their disciplines. The course topics in Basic Math and Algebra include: (1) review of real numbers and simplifying algebraic expressions, (2) translating words to expressions and/or equations, (3) solving linear equations, (4) introduction to the coordinate plane and graphing linear equations, (5) exponential rules, and (6) the definitions, multiplying, and factoring of polynomials.

Watson Glaser Online Assessment. The Watson-Glaser ${ }^{\mathrm{TM}}$ Critical Thinking Appraisal is the most widely used tool for selecting great managers and developing future leaders. Developed in 1925, the Watson-Glaser has been the premier tool for evaluating the cognitive ability of professionals. The Critical Thinking Test is a quick 40-item, multiple test with many reporting options. It is divided into three categories: Recognize Assumptions (RA)-12 questions, Evaluate Arguments (EA)-12 questions, and Draw Conclusions (DC)-16 questions, that assesses student's critical thinking ability in the developmental mathematics courses.

Project Objectives: The objectives of this project are: (1) to help students gain the mathematical skills required to be successful in later math classes and eventually fulfill all the requirements to complete a degree, (2) to increase the development of critical thinking through correcting mistakes on homework/quiz assignments. Students can refer back to previous examples or definitions to try and fix their own errors through the provided online 
videos or examples, and (3) to encourage students to identify the applications of even basic mathematics and connect what they have learned to real world, practical situations.

Hypothesis: Our hypotheses are as follows: (1) students in the developmental math courses will improve critical thinking skills with the implementation of technology in teaching, (2) students in these courses with technology will show a higher increase in math knowledge compared to those in classes without technology.

Participants: Participants were approximately 50 students enrolled in the developmental math courses.

Design: This study used Pretest-Posttest of critical thinking assessment and math content to compare student performance. A pretest was given during the first week of classes and an identical posttest was given during the last week of each semester.

Implementation: Video Lecture Notes with SMART Technology. The video lecture notes were created by instructor with the aid of SMART software. The lecture notes were captured into a notebook and a recording was made of an instructor working through the notes on a tablet PC. These videos combined with the skeleton of notes made it possible for students to review the course materials after class.

Mymathlab Assignments. Homework and quizzes were created through the online learning software-Mymathlab. Questions are carefully chosen to meet with the course objectives of each section. Immediate feedback is given after each question and students are allowed to correct their mistakes by doing a similar exercise. Praise is given for correct answers and hints to solve the problem are provided depending on the incorrect answers. This helps students to apply the core concepts in specific examples and improves student's critical thinking ability. Besides homework assignments, Mymathlab is full of resources including an online version of the textbook, video lectures, and Power Point presentations. Students are encouraged to work ahead, but due dates are required with our current setup to ensure all objectives are met by the end of a semester.

Data Analysis for Math Content Test. For the pretest on Math Content, 29 students completed in the traditional course while 24 students completed in the experimental course by integrating technology in teaching. As the Posttest for math content, 15 students completed in the Traditional condition and 21 students completed for the Experimental condition. 
Figure 1: Descriptive Statistics of Pre-Post Tests Scores in Math Content

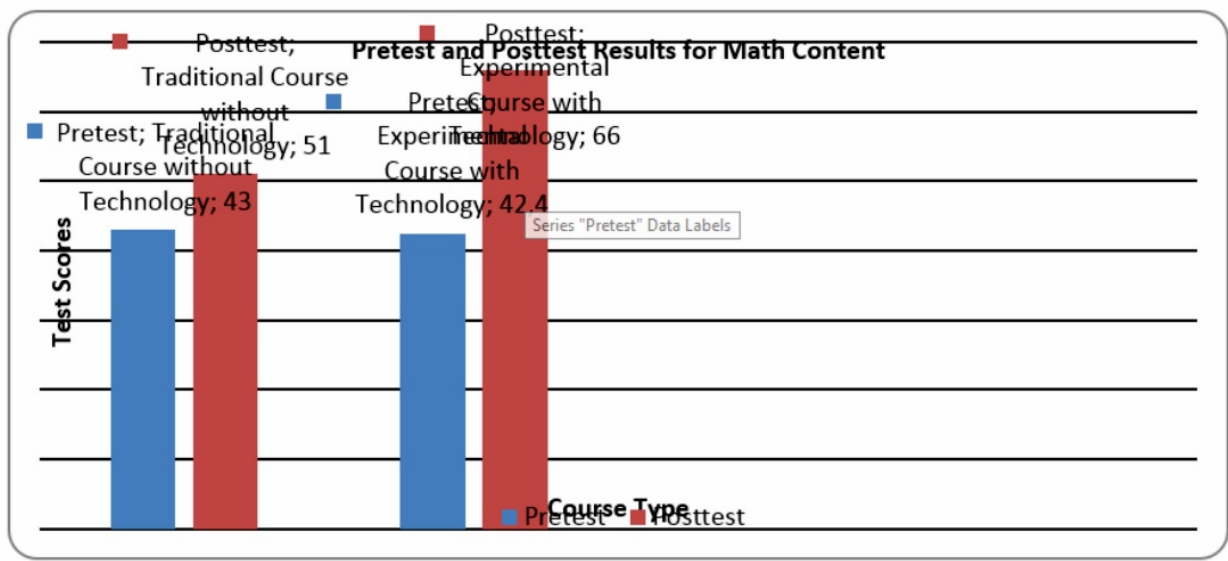

Figure 1 shows that the average of pretests without technology and with technology are 43 and 42.4 respectively. The posttest average for traditional condition is 51 while the average of posttest is 66 under experimental condition. The difference of pretest and posttest is 8 for traditional condition and 23.6 for experimental condition.

Let $d_{1}$ be the mean gain from pretest to posttest in a traditional math course without use and $d_{2}$ be the mean gain from pretest to posttest in an experimental course that uses SMART technology and Mymathlab. Both sections of classes are treated as independent samples and the null hypothesis is: $H_{0}: d_{1}-d_{2} \leq 0$ and the alternative hypothesis is: $H_{A}: d_{1}-d_{2}>0$.

Traditional course without technology:

$n_{1}=15, d_{1}=8, s_{1}=2.6, t_{1}=1.47, p-$ value $\approx 0.081$

2) Experimental course, recorded lecture course:

$n_{2}=21, d_{2}=23.6, s_{2}=2.8, p-$ value $\approx 1.89 \times 10^{-7}$

$t=\frac{d_{2}-d_{1}}{s \sqrt{\frac{1}{n_{2}}+\frac{1}{n_{1}}}} \quad$ with $n_{2}+n_{1}-2$ degrees of freedom and $S=\sqrt{\frac{\left(n_{2}-1\right)^{2} s_{2}^{2}+\left(n_{1}-1\right)^{2} s_{1}{ }^{2}}{n_{2}+n_{1}-2}}$.

After calculation of the t-value, the result shows that it rejects the null hypothesis with $p<0.5$. Thus, the mean gain in math content of the experimental section with technology is higher than the traditional section without technology.

Data Analysis for Critical Thinking Test. 29 students completed the Critical Thinking Pretest in the traditional course without using technology while 24 students completed the Pretest under the Experimental condition by integrating technology in teaching. There were 18 students who completed Critical Thinking Posttest in both Traditional and Experimental condition 
Table 1: Five number summary, mean and standard deviation of number of correct answers in Pretest and each category of Pretest under the traditional condition without technology.

\begin{tabular}{|c|c|c|c|c|c|c|}
\hline \multicolumn{5}{|c|}{ Five-Number Summary of total correct Answers-Pretest (40) } & \multirow{2}{*}{ Mean } & \multirow{2}{*}{$\begin{array}{l}\text { Standard } \\
\text { deviation }\end{array}$} \\
\hline Minimum & $1^{\text {st }}$ Quartile & Median & $3^{\text {rd }}$ Quartile & Maximum & & \\
\hline 10 & 17 & 18 & 19 & 28 & $\begin{array}{c}18.31 \\
(45.78 \%)\end{array}$ & 3.27 \\
\hline \multicolumn{5}{|c|}{$\begin{array}{l}\text { Five-Number Summary of Correct Answers-Recognize Assumption } \\
(12)\end{array}$} & \multirow[t]{2}{*}{ Mean } & \multirow{2}{*}{$\begin{array}{l}\text { Standard } \\
\text { deviation }\end{array}$} \\
\hline Minimum & $1^{\text {st }}$ Quartile & Median & $3^{\text {rd }}$ Quartile & Maximum & & \\
\hline 1 & 4 & 5 & 6 & 8 & $\begin{array}{c}5 \\
(41.67 \%)\end{array}$ & 1.79 \\
\hline \multicolumn{5}{|c|}{ Five-Number Summary of Correct Answers-Evaluate Argument (12) } & \multirow{2}{*}{ Mean } & \multirow{2}{*}{$\begin{array}{l}\text { Standard } \\
\text { deviation }\end{array}$} \\
\hline Minimum & $1^{\text {st }}$ Quartile & Median & $3^{\text {rd }}$ Quartile & Maximum & & \\
\hline 4 & 5 & 6 & 7 & 10 & $\begin{array}{c}6.48 \\
(54 \%)\end{array}$ & 1.74 \\
\hline \multicolumn{5}{|c|}{ Five-Number Summary of Correct Answers-Draw Conclusion (16) } & \multirow{2}{*}{ Mean } & \multirow{2}{*}{$\begin{array}{l}\text { Standard } \\
\text { deviation }\end{array}$} \\
\hline Minimum & $1^{\text {st }}$ Quartile & Median & $3^{\text {rd }}$ Quartile & Maximum & & \\
\hline 2 & 5 & 6 & 8 & 13 & $\begin{array}{c}6.83 \\
(42.69 \%)\end{array}$ & 2.56 \\
\hline
\end{tabular}

Table 2: Five number summary, mean and standard deviation of number of correct answers in Posttest and each category of Posttest under the traditional condition without technology.

Five-Number Summary of total correct Answers-Posttest (40)

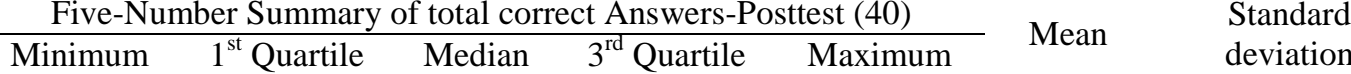
12 16 19

20

28 19 $(47.5 \%)$

4.34

Five-Number Summary of Correct Answers-Recognize Assumption Minimum $\quad 1^{\text {st }}$ Quartile $\quad$ Median $\quad 3^{\text {rd }}$ Quartile $\quad$ Maximum Mean Standard deviation

3

4

5.5

8.75

10

6.28 (52.33\%)

Five-Number Summary of Correct Answers-Evaluate Argument (12) Minimum $\quad 1^{\text {st }}$ Quartile Median $\quad 3^{\text {rd }}$ Quartile Maximum 3 6 7 8 11 Mean 7.11 (59.25\%)

Five-Number Summary of Correct Answers-Draw Conclusion (16) Minimum $1^{\text {st }}$ Quartile Median $3^{\text {rd }}$ Quartile Maximum

5.5

7

8

5.61
$(35.06 \%)$

2.37

Description of Table 1 and 2. Table 1 and 2 gives the five number summary for the Pretest and Posttest of Critical Thinking Test under the traditional condition. The mean of the total correct number of answers is 18.31 (45.78\%) for pretest and 19 (47.5\%) for posttest. The class median is 18 and 19 for pretest and posttest respectively. The mean in each category of the pretest is: $41.67 \%(\mathrm{RA}), 54 \%(\mathrm{EA})$, and $42.69 \%$ (DC), while the mean for posttest is $52.33 \%$ (RA), $59.25 \%$ (EA) and $35.06 \%$ (DC). 
Table 3: Five number summary, mean and standard deviation of number of correct answers in Pretest and each category of Pretest under the experimental condition with technology.

\begin{tabular}{|c|c|c|c|c|c|c|}
\hline \multicolumn{5}{|c|}{ Five-Number Summary of total correct Answers-Pretest (40) } & \multirow[b]{2}{*}{ Mean } & \multirow[b]{2}{*}{$\begin{array}{l}\text { Standard } \\
\text { deviation }\end{array}$} \\
\hline Minimum & $\begin{array}{l}1^{\text {st }} \\
\text { Quartile }\end{array}$ & Median & $3^{\text {rd }}$ Quartile & Maximum & & \\
\hline 10 & 13.75 & 18 & 21 & 23 & $\begin{array}{l}17.29 \\
(43.23 \%)\end{array}$ & 4.27 \\
\hline \multicolumn{5}{|c|}{$\begin{array}{l}\text { Five-Number Summary of Correct Answers-Recognize Assumption } \\
\text { (12) }\end{array}$} & \multirow{2}{*}{ Mean } & \multirow{2}{*}{$\begin{array}{l}\text { Standard } \\
\text { deviation }\end{array}$} \\
\hline Minimum & $\begin{array}{l}1^{\text {st }} \\
\text { Quartile }\end{array}$ & Median & $3^{\text {rd }}$ Quartile & Maximum & & \\
\hline 2 & 3.75 & 5 & 6.25 & 10 & $\begin{array}{l}4.96 \\
(41.33 \%)\end{array}$ & 2.03 \\
\hline \multicolumn{5}{|c|}{ Five-Number Summary of Correct Answers-Evaluate Argument (12) } & \multirow[b]{2}{*}{ Mean } & \multirow[b]{2}{*}{$\begin{array}{l}\text { Standard } \\
\text { deviation }\end{array}$} \\
\hline Minimum & $\begin{array}{l}1^{\text {st }} \\
\text { Quartile }\end{array}$ & Median & $3^{\text {rd }}$ Quartile & Maximum & & \\
\hline 2 & 4 & 6 & 7.25 & 9 & $\begin{array}{l}5.92 \\
(49.33 \%)\end{array}$ & 1.98 \\
\hline \multicolumn{5}{|c|}{ Five-Number Summary of Correct Answers-Draw Conclusion (16) } & \multirow[b]{2}{*}{ Mean } & \multirow{2}{*}{$\begin{array}{l}\text { Standard } \\
\text { deviation }\end{array}$} \\
\hline Minimum & $\begin{array}{l}1^{\text {st }} \\
\text { Quartile }\end{array}$ & Median & $3^{\text {rd }}$ Quartile & Maximum & & \\
\hline 3 & 5 & 6 & 7.25 & 11 & $\begin{array}{l}6.42 \\
(40.13 \%)\end{array}$ & 2.04 \\
\hline
\end{tabular}

Table 4: Five number summary, mean and standard deviation of number of correct answers in Posttest and each category of Posttest under the experimental condition with technology.

\begin{tabular}{|c|c|c|c|c|c|c|}
\hline \multicolumn{5}{|c|}{ Five-Number Summary of total correct Answers-Posttest (40) } & \multirow{2}{*}{ Mean } & \multirow{2}{*}{$\begin{array}{l}\text { Standard } \\
\text { deviation }\end{array}$} \\
\hline Minimum & $1^{\text {st }}$ Quartile & Median & $3^{\text {rd }}$ Quartile & Maximum & & \\
\hline 14 & 17.25 & 19 & 21.75 & 27 & $\begin{array}{c}19.67 \\
(49.18 \%)\end{array}$ & 4.03 \\
\hline \multicolumn{5}{|c|}{$\begin{array}{c}\text { Five-Number Summary of Correct Answers-Recognize } \\
\text { Assumption (12) }\end{array}$} & \multirow[t]{2}{*}{ Mean } & \multirow{2}{*}{$\begin{array}{l}\text { Standard } \\
\text { deviation }\end{array}$} \\
\hline Minimum & $1^{\text {st }}$ Quartile & Median & $3^{\text {rd }}$ Quartile & Maximum & & \\
\hline 2 & 5 & 7 & 8 & 10 & $\begin{array}{c}6.56 \\
(54.67 \%)\end{array}$ & 2.36 \\
\hline \multicolumn{5}{|c|}{$\begin{array}{l}\text { Five-Number Summary of Correct Answers-Evaluate Argument } \\
\text { (12) }\end{array}$} & \multirow[t]{2}{*}{ Mean } & \multirow{2}{*}{$\begin{array}{l}\text { Standard } \\
\text { deviation }\end{array}$} \\
\hline Minimum & $1^{\text {st }}$ Quartile & Median & $3^{\text {rd }}$ Quartile & Maximum & & \\
\hline 3 & 6 & 7 & 7 & 11 & $\begin{array}{c}6.5 \\
(54.17 \%)\end{array}$ & 1.72 \\
\hline \multicolumn{5}{|c|}{$\begin{array}{l}\text { Five-Number Summary of Correct Answers-Draw Conclusion } \\
\qquad(16)\end{array}$} & \multirow[t]{2}{*}{ Mean } & \multirow{2}{*}{$\begin{array}{l}\text { Standard } \\
\text { deviation }\end{array}$} \\
\hline Minimum & $1^{\text {st }}$ Quartile & Median & $3^{\text {rd }}$ Quartile & Maximum & & \\
\hline 3 & 5 & 7 & 8 & 11 & $\begin{array}{c}6.61 \\
(41.31 \%)\end{array}$ & 2.12 \\
\hline
\end{tabular}

Description of Table 3 and 4. The five number summary of the Pretest and Posttest of the Critical Thinking Test in the experimental condition is displayed in Table 3 and 4 . The mean of the total correct 
number of answers is 17.29 (43.223\%) for pretest and 19.67 (49.18\%) for posttest. The class median remains the same as the traditional condition. The mean in each category of the pretest becomes: $41.33 \%$ (RA), $49.33 \%$ (EA), and $40.13 \%$ (DC), while the mean for posttest changes to: $54.67 \%$ (RA), $54.17 \%$ (EA) and $41.31 \%$ (DC).

Table 5: Differences of Means of Pretest total and Posttest total in both conditions.

\begin{tabular}{|c|c|c|c|}
\hline & Pretest Mean & Posttest Mean & Difference \\
\hline Experimental Condition & $43.23 \%$ & $49.18 \%$ & $5.95 \%$ increase \\
\hline Traditional Condition & $45.78 \%$ & $47.5 \%$ & $1.72 \%$ increase \\
\hline
\end{tabular}

Table 6: Differences of Means of Each category of Pretest and Posttest in both conditions.

\begin{tabular}{|c|c|c|c|}
\hline & $\begin{array}{c}\text { Difference in RA } \\
\text { Mean }\end{array}$ & $\begin{array}{c}\text { Difference in EA } \\
\text { Mean }\end{array}$ & $\begin{array}{c}\text { Difference in DC } \\
\text { Mean }\end{array}$ \\
\hline $\begin{array}{c}\text { Experimental } \\
\text { Condition }\end{array}$ & $13.3 \%$ increase & $4.8 \%$ increase & $1.2 \%$ increase \\
\hline Traditional Condition & $10.7 \%$ & $5.3 \%$ increase & $7.6 \%$ decrease \\
\hline
\end{tabular}

Comparison of Pretest and Posttest in both conditions. Looking at the difference of the mean for Pretest and Posttest in Table 5, there is a $5.95 \%$ increase for the traditional course and 1.72\% increase for the experimental course. Under both conditions (see Table 6), there is a large increase in the category of Recognize Assumption and an increase in Evaluate Argument. However, the traditional class has a slightly increase and the experimental has a huge decrease in the category of Draw Conclusion.

\section{Conclusion}

Comparing the pretest and posttest in math content and critical thinking, this study showed there were gains in the math content from pretest to posttest under both traditional and experimental condition. There is an 8 points increase for the traditional class without technology while a 23.6 points increase for the experimental class with technology. The increase under Experimental condition is approximately three times the increase under the traditional condition. As for the Critical Thinking Test, both classes has a relatively small increase between pretest and posttest. However, the increase for the experimental class is also triple of the increase for the traditional class. Thus it follows that the model of integrating technology into teaching developmental math courses should be adapted.

\section{References:}

Allen, R. D., (1981). Intellectual Development and the Understanding of Science: Applications of William Perry's Theory to Science Teaching. Journal of College Science Teaching, 11 (2), 94-97. 
Arons, A. B., (1985). Critical Thinking' and the Baccalaureate Curriculum. Liberal Education, 71 (2), 141-157.

Bean, J., (1996). Helping Students Read Difficult Texts. Engaging Ideas: The Professor's Guide to Integrating Writing, Critical Thinking, and Active Learning in the Classroom. San Francisco: Jossey-Bass, 133-147.

Brouwer, P., (1996). Hold on a Minute Here: What Happened to Critical Thinking in the Information Age?, Journal of Educational Technology Systems, 25, 189-197.

Dewey, J., (1910). How we think. Lexington, MA: D.C. Heath \& Company. Law, J. (1998). Critical Thinking and Computer-aided Instruction in Sociology 200. Writing Across the Curriculum.

McPeck, J. E., (1982). The Meaning of Critical Thinking. Canadian Journal of Education, 7 (4), 107-110.

Moll, M. B., and Allen, R. D., (1982). Developing Critical Thinking Skills in Biology, Journal of College Science Teaching, 4, 95- 98.

Nelson, C. E., (1994). Critical Thinking and Collaborative Learning, New Directions for Teaching and Learning, 59, 45-58.

Reichenbach, B., (2000). An Introduction to Critical Thinking. 